\title{
New and emerging combination therapies for esophageal cancer
}

\author{
This article was published in the following Dove Press journal: \\ Cancer Management and Research \\ 26 June 2013 \\ Number of times this article has been viewed
}

\author{
Marcus W Wiedmann ${ }^{1,2}$ \\ Joachim Mössner ${ }^{2}$ \\ 'Department of Internal Medicine I, \\ St Mary's Hospital, Berlin, Germany; \\ ${ }^{2}$ Division of Gastroenterology \\ and Rheumatology, Department \\ of Medicine, Neurology and \\ Dermatology, University Hospital \\ of Leipzig, Leipzig, Germany
}

\begin{abstract}
Esophageal cancer comprises two different histological forms - squamous cell carcinoma (SCC) and adenocarcinoma (AC). While the incidence of AC has increased steeply in Western countries during the last few years, the incidence of SCC is fairly stable. Both forms differ in pathogenesis and response to chemotherapy and radiation therapy. Plenty of studies have evaluated new chemotherapy combination regimens in the neoadjuvant, adjuvant, and palliative setting. In addition, new radiation and chemoradiation protocols have been investigated. Finally, molecular-targeted therapy has been included in several new randomized prospective trials. Therefore, this review presents new data on this topic and critically discusses promising approaches towards a more effective treatment in a disease with a grim prognosis.
\end{abstract}

Keywords: chemotherapy, chemoradiation, molecular targeted therapy

\section{Introduction}

The crude incidence of esophageal cancer in the European Union is about four to five cases per 100,000 population. In Germany, the tumor holds ninth place of all cancer casualties for men and 15th place for women. It comprises two different histological forms, squamous cell carcinoma (SCC) and adenocarcinoma (AC). In contrast to Asian countries, the incidence of AC has increased steeply in Western countries, based on an increased incidence of Barrett's esophagus as the precursor. In contrast, the incidence of SCC has been fairly stable during the last decade. The tumor TNM staging system, as outlined by the Union for International Cancer Control, groups esophageal cancer in different stages (Table 1). ${ }^{1}$ Local endoscopic resection \pm thermal ablation (photodynamic therapy, and endoscopic radio-frequency ablation of Barrett's esophagus with dysplasia) is indicated for tumors restricted to the mucosa with a size $<2 \mathrm{~cm}$. $\mathrm{T} 2$ tumors without metastases are suitable for primary surgery; in most cases, subtotal en bloc esophagectomy with two-field lymphadenectomy is preferred. T3 tumors and T4 tumors should be primarily treated with neoadjuvant chemotherapy (mainly AC) or chemoradiation (SCC and $\mathrm{AC}$ ) to increase the chance of curative (R0) resection. Definitive chemoradiation (or chemotherapy in the case of distant metastases) should be provided to functional nonoperable patients. In the case of nonresectable obstructive tumor growth, endoscopic metal stent placement as the best supportive care may give relief in these patients. The prognosis of esophageal cancer is very poor. About $50 \%$ of patients have advanced disease at the diagnosis, and the natural course encompasses only 8 to 10 months overall survival (OS) time, with a 5 -year survival rate of $5 \%-17 \%$. In addition, though some patients receive curative surgical treatment, the disease recurs
Correspondence: Marcus W Wiedmann Department of Internal Medicine I, St Mary's Hospital, Gallwitzallee I23-I43, I2249 Berlin, Germany

Tel +493076783251

Fax +49307678 3425

Email wiedmann@marienkrankenhausberlin.de 
Table I TNM- and UICC-classification of esophageal cancer 2010

\begin{tabular}{|c|c|c|c|}
\hline $\mathrm{TX}$ & \multicolumn{3}{|c|}{ Primary tumor cannot be assessed } \\
\hline T0 & \multicolumn{3}{|c|}{ No evidence of primary tumor } \\
\hline Tis & \multicolumn{3}{|l|}{ High-grade dysplasia } \\
\hline Tla & \multicolumn{3}{|c|}{ Tumor invades lamina propria or muscularis mucosae } \\
\hline TIb & \multicolumn{3}{|c|}{ Tumor invades submucosa } \\
\hline $\mathrm{T} 2$ & \multicolumn{3}{|c|}{ Tumor invades muscularis propria } \\
\hline T3 & \multicolumn{3}{|c|}{ Tumor invades adventitia } \\
\hline T4a & \multicolumn{3}{|c|}{ Tumor invades pleura, pericardium, or diaphragm } \\
\hline $\mathrm{T} 4 \mathrm{~b}$ & \multicolumn{3}{|c|}{$\begin{array}{l}\text { Tumor invades neighboring structures, such as aorta, } \\
\text { vertebral body, or trachea }\end{array}$} \\
\hline NX & \multicolumn{3}{|c|}{ Regional lymph nodes cannot be assessed } \\
\hline No & \multicolumn{3}{|c|}{ No regional lymph node metastasis } \\
\hline NI & \multicolumn{3}{|c|}{ I-2 regional lymph node metastases } \\
\hline N2 & \multicolumn{3}{|c|}{$3-6$ regional lymph node metastases } \\
\hline N3 & \multicolumn{3}{|c|}{$\geq 7$ regional lymph node metastases } \\
\hline$M X$ & \multicolumn{3}{|c|}{ Distant metastasis cannot be assessed } \\
\hline MO & \multicolumn{3}{|l|}{ No distant metastasis } \\
\hline MI & \multicolumn{3}{|l|}{ Distant metastasis } \\
\hline Stage 0 & Tis & No & Mo \\
\hline Stage IA & TI & No & Mo \\
\hline Stage IB & T2 & No & Mo \\
\hline Stage IIA & T3 & No & Mo \\
\hline Stage IIB & TI, T2 & $\mathrm{NI}$ & Mo \\
\hline \multirow[t]{3}{*}{ Stage IIIA } & $\mathrm{T} 4 \mathrm{a}$ & No & Mo \\
\hline & T3 & NI & Mo \\
\hline & TI, T2 & N2 & Mo \\
\hline Stage IIIB & T3 & N2 & Mo \\
\hline \multirow[t]{3}{*}{ Stage IIIC } & $\mathrm{T} 4 \mathrm{a}$ & $\mathrm{N} 1, \mathrm{~N} 2$ & Mo \\
\hline & $\mathrm{T} 4 \mathrm{~b}$ & any $\mathrm{N}$ & Mo \\
\hline & any $T$ & N3 & Mo \\
\hline Stage IV & any $T$ & any $\mathrm{N}$ & MI \\
\hline
\end{tabular}

Abbreviations: TNM, TNM Classification of Malignant Tumors; UICC, Union for International Cancer Control.

and metastasizes in up to $65 \%$ of patients after 5 years. (For further review, see Mawhinney et $\mathrm{al}^{2}{ }^{2}$ ) Therefore, there is a need for new treatment strategies, which will be discussed in the review article.

\section{Perioperative treatment of esophageal cancer Neoadjuvant chemotherapy}

A recent meta-analysis including ten studies and 2062 randomized patients with AC and SCC showed a significant improvement in OS after neoadjuvant chemotherapy, with a relative risk reduction of $13 \%$ (hazard ratio [HR] $0.87 ; 95 \%$ CI [confidence interval], 0.79-0.96; $P=0.005$ ), resulting in a 2-year survival increase of $5.1 \%$. While this difference was not significant for patients with SCC (HR 0.92; 95\% CI, 0.81-1.04; $P=0.18$ ), it was highly significant for patients with AC (HR 0.83; 95\% CI, 0.71-0.95; $P=0.01){ }^{3}$ However, in Japan, neoadjuvant chemotherapy for SCC with cisplatin/5-fluorouracil (FU) is still regarded as standard treatment and cannot be replaced by adjuvant chemotherapy with the same regimen. ${ }^{4}$

\section{Perioperative (neoadjuvant and adjuvant) chemotherapy}

Perioperative chemotherapy of distal esophageal and esophagogastric junction cancer was first established with the Phase III UK Medical Research Council Adjuvant Gastric Infusional Chemotherapy-study, published in 2006 in the New England Journal of Medicine and primarily designed for stomach cancer patients. ${ }^{5}$ In this trial, a perioperative epirubicin/ cisplatin/5-FU (ECF) regimen $(n=250)$ decreased tumor size and stage and significantly improved progression-free survival (PFS) (HR 0.66; 95\% CI, 0.53-0.81; $P<0.001)$ and OS (HR $0.75 ; 95 \% \mathrm{CI}, 0.6-0.93 ; P=0.009)$ in comparison to surgery alone $(\mathrm{n}=253)$. Cisplatin/5-FU regimen as an alternative in this setting (distal esophageal, esophagogastric junction, and stomach cancer) was published 5 years later, derived from the results of the French Fédération Francophone de Cancérologie Digestive (FFCD) multicenter Phase III trial ( $\mathrm{n}=113$ for perioperative chemotherapy and $n=111$ for surgery alone). ${ }^{6}$ This trial showed a significantly increased curative resection rate, disease-free survival (HR 0.65; 95\% CI, 0.48-0.89; $P=0.003$ ) and OS (HR 0.69; 95\% CI, 0.5-0.95; $P=0.02$ ). Recently, two Phase II studies (both on distal esophageal, esophagogastric junction, and stomach cancer) evaluated docetaxel/cisplatin/ capecitabine $(\mathrm{DCX})^{7}(\mathrm{n}=51)$ and docetaxel/cisplatin/5-FU $(\mathrm{DCF})^{8}(\mathrm{n}=43)$ combinations as alternative tolerable and highly effective regimens because disadvantages of ECF include anthracycline-induced cardiotoxicity and a lengthy 21-day continuous infusion of 5-FU at each cycle.

\section{Neoadjuvant-targeted therapy}

In contrast, addition of angiogenesis inhibitor bevacizumab to neoadjuvant chemotherapy with cisplatin/5-FU showed no extra benefit in patients with SCC $(\mathrm{n}=6)$ or $\mathrm{AC}(\mathrm{n}=22)$ in comparison to a historical control group $(n=37)$ that was treated with cisplatin/5-FU alone. ${ }^{9}$ In this study, the response rate (RR) was $39 \%$; the $\mathrm{R} 0$ resection rate was $43 \%$; and the median OS was 17 months for the experimental group. The triple regimen was well-tolerated, with the most common severe toxicities being venous thromboembolism (10\%), nausea (7\%), and gastrointestinal bleeding (7\%).

\section{Adjuvant chemoradiation}

In the pivotal Intergroup-0116 Phase III trial by Macdonald et al, ${ }^{10}$ adjuvant chemoradiation (without 
preoperative chemotherapy) improved both disease-free survival (HR 1.52; 95\% CI, 1.23-1.86; $P<0.001$ ) and OS (HR 1.35; 95\% CI, 1.09-1.66; $P=0.005$ ) in curatively resected patients with mainly gastric and esophagogastric junction adenocarcinoma. ${ }^{10}$ Updated results from last year confirmed that adjuvant chemoradiation (45 gray [Gy] radiation dose) remains a rational standard therapy for curatively resected gastric and esophagogastric junction cancer with primaries T3 or greater and/or positive nodes $(n=559$ in the study), at least in the United States, where D2 resection is less common than in Europe or Japan. ${ }^{11}$ For this reason, the Intergroup-0116 study was criticized in Asia and Europe, because a majority of patients received less than a D1 lymph node dissection at surgery, while fewer than $10 \%$ underwent the more extensive D2 resection. This led to speculation that postoperative chemoradiation simply compensated for inadequate surgery. Although significantly fewer local and regional recurrences were found in the chemoradiation group, the absolute number of local recurrences was too small to draw definitive conclusions. However, a Danish Phase II study examining only patients with esophagogastric junction adenocarcinoma recently confirmed the Intergroup-0166 results (116 patients were treated with adjuvant chemoradiation). ${ }^{12}$ Median time of survival was prolonged by 10 months in favor of those who received chemoradiation.

\section{Perioperative chemoradiation}

More recently, the Southwest Oncology Group designed a trimodal, Phase II, single-arm trial with the objective of achieving a pathological complete remission $(\mathrm{pCR})$ rate of $40 \%$ after neoadjuvant treatment with oxaliplatin/5FU/radiation and adjuvant chemotherapy in esophageal adenocarcinoma. ${ }^{13}$ Ninety-three patients were evaluable. Seventy-nine patients (84.9\%) underwent surgery, and 67.7\% of patients had R0 resections. Twenty-six patients $(28.0 \%)$ had confirmed pCR (95\% CI, 19.1\%-38.2\%). At a median follow-up of 39.2 months, estimates of median and 3-year OS were 28.3 months and $45.1 \%$, respectively.

\section{Neoadjuvant chemoradiation}

After a neoadjuvant combination of irinotecan/cisplatin/ radiation $69 \%$ of $A C$ and SCC patients $(n=55)$ of another Phase II study underwent $\mathrm{R} 0$ resection. The incidence of $\mathrm{pCR}$ was $16 \%$ (95\% CI 8\%-29\%). Median OS was 31.7 months. ${ }^{14}$ Neoadjuvant treatment with docetaxel, cisplatin, 5-FU, and radiation in untreated stage II-III AC and SCC of mid-distal thoracic esophagus was also investigated in another recent Phase II study. ${ }^{15}$ pCR was found in 47\% (35 of 74) and near
pCR (microfoci of tumor cells on the primary tumor without lymph nodal metastases [pnCR]) in $15 \%$ of the patients (11 of 74). Median survival of all 74 patients was 55 months, while in the pCR subset the median survival could not be calculated, as $>50 \%$ of the patients were still alive. The large Phase III Chemoradiotherapy for Oesophageal Cancer Followed by Surgery Study (CROSS) study from the Netherlands additionally established a neoadjuvant carboplatin/paclitaxel/radiation regimen. ${ }^{16}$ Two hundred seventy-five patients (75\%) had adenocarcinoma, 84 (23\%) had squamous cell carcinoma, and 7 (2\%) had large-cell undifferentiated carcinoma. Complete resection (R0) was achieved in $92 \%$ of patients in the chemoradiation-surgery group versus $69 \%$ in the surgery group $(P<0.001)$. Postoperative complication rate was similar in the two treatment groups, and in-hospital mortality was $4 \%$ in both. Median OS was 49.4 months in the chemoradiationsurgery group versus 24.0 months in the surgery group (HR 0.657; 95\% CI, 0.495-0.871; $P=0.003$ ). Finally, two meta-analyses of older randomized-controlled trials for neoadjuvant chemoradiation showed a clear benefit in terms of OS in comparison to surgery alone, especially for patients with adenocarcinoma. ${ }^{3,17}$ In detail, the meta-analysis by Jin et $\mathrm{al}^{17}$ comprised eleven randomized-controlled trials from 1992 to 2008 , including 1308 patients. ${ }^{18-28}$ The meta-analysis by Sjoquist et $\mathrm{al}^{3}$ included 17 randomizedcontrolled trials from their previous meta-analysis and seven further studies. Twelve were randomized comparisons of neoadjuvant chemoradiotherapy versus surgery alone $(\mathrm{n}=1854)$; $^{16,18-26,29,30}$ nine were randomized comparisons of neoadjuvant chemotherapy versus surgery alone $(n=1981)$; and two compared neoadjuvant chemoradiotherapy with neoadjuvant chemotherapy $(n=194)$ in patients with resectable esophageal carcinoma. One factorial trial included two comparisons and was included in analyses of both neoadjuvant chemoradiation $(\mathrm{n}=78)$ and neoadjuvant chemotherapy $(n=81)$.

\section{Neoadjuvant chemoradiation plus targeted therapy}

In contrast, the addition of molecular-targeted therapy with bevacizumab and erlotinib to neoadjuvant chemoradiation (paclitaxel/carboplatin/5-FU/radiation) in AC/SCC-patients (including tumors of the gastroesophageal junction) did not demonstrate a survival benefit or improved pathologic complete response rate over similar regimens $(n=62)$. While the overall rates of toxicity were not increased, targeted agent-specific toxicity (grade 3/4 leukopenia in 64\%; grade 
$3 / 4$ neutropenia in $44 \%$; grade $3 / 4$ mucositis/stomatitis in $42 \%$; grade $3 / 4$ diarrhea in $27 \%$; and grade $3 / 4$ esophagitis in $27 \%$ ) was evident. ${ }^{31}$

\section{Definitive chemoradiation}

A randomized-controlled Phase III study from the US (Radiation Therapy Oncology Group trial 85-01) clearly demonstrated superiority of chemoradiation in comparison to radiation alone in patients with SCC and AC. ${ }^{32}$ However, chemotherapy could be administered as planned in only $89(68 \%)$ of 130 patients ( $10 \%$ had life-threatening toxic effects with combined therapy versus $2 \%$ in the radiation-only group). Stahl et $\mathrm{l}^{33}$ compared chemoradiation (etoposide and cisplatin, $40 \mathrm{~Gy}$ ) followed by surgery ( $\operatorname{arm~A;~} \mathrm{n}=86$ ) with definitive chemoradiation (60 Gy) ( $\operatorname{arm} \mathrm{B} ; \mathrm{n}=86)$. The OS was equivalent in both SCC groups; local PFS was better in arm A (HR 2.1; 95\% CI, 1.3-3.5; $P=0.003)$, but treatment-related mortality less in arm $\mathrm{B}(3.5 \%$ versus $12.8 \% ; P=0.03) .{ }^{33}$ These results were confirmed by a similar randomized French trial (259 patients were randomly assigned) using 5-FU and cisplatin as combination partners for radiation (only SCC patients). ${ }^{34}$ Median survival time was 17.7 months in the surgery group versus 19.3 months in the definitive chemoradiation group. A third prospectively randomized study from Hong Kong (81 patients were randomly assigned) demonstrated a remarkable 5-year survival rate of $48.6 \%$ for the definitive chemoradiation (5-FU/cisplatin/50-60 Gy) group and a trend to improved 5-year survival in node-positive disease (only SCC patients). ${ }^{35}$ In a recent study presented at ASC0 2012 (PRODIGE 5/ACCORD 17 trial; Conroy et al; LBA $4003)^{36}$ patients with nonoperable localized esophageal carcinoma ( $85 \%$ SCC; $15 \% \mathrm{AC}$ ) were randomized to two different chemoradiation protocols. Radiation dose was 50 Gy in both arms. Patients in arm A received six cycles of FOLFOX (5-FU/oxaliplatin) every 2 weeks; patients in arm B had four cycles of 5-FU/cisplatin every 3 weeks. PFS (9.7 months versus 9.4 months), the primary study end point, and OS survival (20.2 months versus 17.5 months) were similar in both arms. Addition of epithelial derived growth factor receptor (EGFR) 1 inhibitor cetuximab to a capecitabine/cisplatin/radiation backbone did result in greater toxicity, a lower rate of completion of standard therapy, and significantly worse survival (22 months versus 25 months; $P=0.043$ ) in patients with locally advanced SCC $(73 \%)$ or $\mathrm{AC}(27 \%)$ as demonstrated by a recent large UK study (SCOPE-1, National Clinical Trial [NCT]00509561, Crosby et al; 2013 Gastrointestinal Cancers Symposium,
LBA3). ${ }^{37}$ Docetaxel/cisplatin/radiation combination is feasible too, as demonstrated in a Korean Phase II study (36 SCC patients). ${ }^{38}$ In a recent meta-analysis of three randomized studies, definitive chemoradiation in patients with SCC did not demonstrate any survival benefit over other curative strategies, but treatment-related mortality rates were lower (HR 7.60; $P=0.007) .{ }^{39}$ A study from Korea suggested vascular endothelial growth factor (VEGF) as a positive predictive factor and cyclooxygenase-2 (COX-2) as a negative prognostic factor for OS in patients with SCC after definitive chemoradiation. ${ }^{40}$

\section{Palliative first-line treatment of esophageal cancer Chemotherapy}

In past decades, there was not much improvement in the outcome and survival of advanced esophageal cancer due to the lack of effective chemotherapy agents. The traditional chemotherapy drugs to treat esophageal cancer include 5 -FU and cisplatin, and the combination of them results in a 25\%-35\% RR in both first-line and second-line treatment (Table 2). ${ }^{41}$ Unfortunately, the main side effect of cisplatin is renal toxicity. The peak age of esophageal cancer patients is 65 to 70 years, and many of them have other diseases at the same time, such as hypertension, diabetes, and chronic kidney disease, which cause varying damage to renal function, and limit the use of cisplatin in these patients. Therefore, it is both urgent and crucial to seek an alternative to cisplatin in the combination chemotherapy treatment. Due to high-response rates in Asian patients, a combination of cisplatin/oral fluoropyrimidine (S-1) was compared with cisplatin/infusional 5-FU in patients with advanced gastric or gastroesophageal adenocarcinoma (FLAGS trial). ${ }^{42}$ One thousand fifty-three patients were stratified, and the primary end point was superiority in OS from cisplatin/S-1 (Table 2). Although this goal was not met in the cisplatin/S-1 arm (HR 0.92; 95\% CI, 0.80-1.05; $P=0.20$ ), significant safety advantages were observed in the cisplatin/S-1 arm, compared with the cisplatin/infusional fluorouracil arm, for the rates of grade $3 / 4$ neutropenia $(32.3 \%$ versus $63.6 \%$ ), complicated neutropenia $(5.0 \%$ versus $14.4 \%)$, stomatitis ( $1.3 \%$ versus $13.6 \%)$, hypokalemia (3.6\% versus $10.8 \%)$, and treatment-related deaths $(2.5 \%$ versus $4.9 \% ; P<0.05)$. 5 -FU can also be replaced by oral capecitabine ${ }^{43}$ (Xeloda [Roche, Basel, Switzerland] platinum regimen) and cisplatin by oxaliplatin, ${ }^{44}$ based on Phase II studies. Dual replacement was also successful. ${ }^{45,46}$ Regarding toxicity, 5-FU/leucovorin/oxaliplatin (FLO) seems to be less toxic 
Table 2 Prospective clinical trials of first-line chemotherapy of esophageal cancer

\begin{tabular}{|c|c|c|c|c|c|c|}
\hline Design & Treatment & $\mathbf{n}$ & Histology & $\mathbf{R R}$ & Median OS & Reference \\
\hline Phase II & Cisplatin/5-FU & 44 & SCC & $35 \%$ & 8.25 months & 41 \\
\hline Phase II & Paclitaxel/5-FU/cisplatin & 60 & SCC/AC & $48 \%$ & 10.8 months & 49 \\
\hline Phase II & Cisplatin/irinotecan & 35 & SCC/AC & $57 \%$ & I4.6 months & 50 \\
\hline Phase II & Cisplatin/vinorelbine & 71 & SCC & $34 \%$ & 6.8 months & 51 \\
\hline Phase II & Oxaliplatin/5-FU & 35 & SCC/AC & $40 \%$ & 7.1 months & 44 \\
\hline Phase II & $\begin{array}{l}\text { Docetaxel/ } \\
\text { capecitabine }\end{array}$ & 16 & $\begin{array}{l}\text { SCC/AC } \\
+\mathrm{GEJ}\end{array}$ & $56 \%$ & I5.8 months & 54 \\
\hline Phase II & $\begin{array}{l}\text { Docetaxel/cisplatin } \\
\text { Docetaxel/cisplatin/5-FU }\end{array}$ & $\begin{array}{l}76 \\
79\end{array}$ & $\begin{array}{l}\text { GEJ + } \\
\text { GASTRIC }\end{array}$ & $\begin{array}{l}26 \% \\
43 \%\end{array}$ & $\begin{array}{l}10.5 \text { months } \\
9.6 \text { months }\end{array}$ & 56 \\
\hline Phase II & Docetaxel/capecitabine & 44 & GEJ + GASTRIC & $39 \%$ & 9.4 months & 53 \\
\hline Phase II & $\begin{array}{l}\text { Oxaliplatin/ } \\
\text { capecitabine }\end{array}$ & 43 & $\begin{array}{l}\text { AC + } \\
\text { GEJ + } \\
\text { GASTRIC }\end{array}$ & $35 \%$ & 6.4 months & 46 \\
\hline $\begin{array}{l}\text { Phase II } \\
\text { (first, second I) }\end{array}$ & $\begin{array}{l}\text { Oxaliplatin/ } \\
\text { capecitabine }\end{array}$ & 51 & $\begin{array}{l}\text { SCC/AC } \\
+\mathrm{GEJ}\end{array}$ & $39 \%$ & 8 months & 45 \\
\hline Phase II & $\begin{array}{l}\text { Docetaxel/ } \\
\text { capecitabine/ } \\
\text { carboplatin }\end{array}$ & 25 & $\begin{array}{l}\text { AC }+ \\
\text { GEJ }+ \\
\text { GASTRIC }\end{array}$ & $48 \%$ & 8 months & 58 \\
\hline Phase II & Docetaxel/cisplatin/5-FU & 60 & GEJ + GASTRIC & $47 \%$ & 17.9 months & 57 \\
\hline Phase III & $\begin{array}{l}\text { ECF } \\
\text { ECX } \\
\text { EOF } \\
\text { EOX }\end{array}$ & $\begin{array}{l}249 \\
241 \\
235 \\
239\end{array}$ & $\begin{array}{l}\text { SCC }+ \\
\text { AC }+ \\
\text { GEJ }+ \\
\text { GASTRIC }\end{array}$ & $\begin{array}{l}41 \% \\
46 \% \\
42 \% \\
48 \%\end{array}$ & $\begin{array}{l}9.9 \text { months } \\
9.9 \text { months } \\
9.3 \text { months } \\
\text { II. } 2 \text { months }\end{array}$ & 55 \\
\hline Phase II & Cisplatin/paclitaxel & 35 & SCC & $49 \%$ & 13 months & 48 \\
\hline Phase II & Capecitabine/cisplatin & 45 & $\mathrm{SCC}$ & $58 \%$ & II.2 months & 43 \\
\hline Phase III & $\begin{array}{l}\text { Cisplatin/S-I } \\
\text { Cisplatin/5-FU }\end{array}$ & $\begin{array}{l}82 \\
88\end{array}$ & $\begin{array}{l}\text { GEJ + } \\
\text { GASTRIC }\end{array}$ & $\begin{array}{l}29 \% \\
32 \%\end{array}$ & $\begin{array}{l}8.6 \text { months } \\
7.9 \text { months }\end{array}$ & 42 \\
\hline Phase II & $\begin{array}{l}\text { Docetaxel/cisplatin/ } \\
\text { 5-FU }\end{array}$ & 50 & $\begin{array}{l}\text { SCCIAC + } \\
\text { GEJ + } \\
\text { GASTRIC }\end{array}$ & $47 \%$ & II.2 months & 59 \\
\hline $\begin{array}{l}\text { Phase II } \\
\text { (first, second I) }\end{array}$ & $\begin{array}{l}\text { Paclitaxel/ } \\
\text { capecitabine }\end{array}$ & 32 & SCC & $\begin{array}{l}75 \% \\
45 \%\end{array}$ & $\begin{array}{l}14.3 \text { months } \\
8.4 \text { months }\end{array}$ & 52 \\
\hline Phase II & Cisplatin/paclitaxel & 46 & SCC & $57 \%$ & 17 months & 60 \\
\hline
\end{tabular}

Notes: $* p<0.05 ; * * p<0.01$.

Abbreviations: 5-FU, 5-fluorouracil; AC, adenocarcinoma; ECF, epirubicin/cisplatin/5-FU; ECX, epirubicin/capecitabine/5-FU; EOF, epirubicin/oxaliplatin/5-FU; EOX, epirubicin/oxaliplatin/capecitabine; GASTRIC, gastric cancer; GEJ, gastroesophageal junction carcinoma; S-I, oral fluoropyrimidine; SCC, squamous cell carcinoma; OS, overall survival; RR, response rate.

than 5-FU/leucovorin/cisplatin (FLP), according to a Phase III study that included mostly gastric cancer patients but also patients with gastroesophageal tumors. ${ }^{47} \mathrm{~A}$ paclitaxelplus-cisplatin regimen is another promising treatment of esophageal cancer and has been proven effective at Phase II level (Table 2).$^{48}$ This combination has become a standard treatment of esophageal cancer, especially of SCC. In addition, paclitaxel or docetaxel can be combined with capecitabine (Table 2). ${ }^{52-54}$

In $\mathrm{AC}$ patients with a good general condition triplet regimen, such as ECF, epirubicin/cisplatin/capecitabine (ECX), epirubicin/oxaliplatin/5-FU (EOF), and epirubicin/ oxaliplatin/capecitabine (EOX), or DCF/DCX, and DCC (docetaxel/carboplatin/capecitabine) are even more effective regarding response rate; however, toxicity is markedly increased (Table 2). ${ }^{55-59}$

\section{Targeted therapy}

EGFR, a member of the ErbB tyrosine kinase family, is a target that was examined in several studies. Binding of the ligand leads to receptor dimerization and consecutively to activation of downstream signals regulating cell cycle, apoptosis, cell proliferation, and angiogenesis. Overexpression of EGFR was detected in 30\%-90\% of esophagogastric tumors, correlating with increased invasion, dedifferentiation, and worse prognosis. ${ }^{61-64}$ In contrast to colorectal and lung cancer, KRAS mutation status and EGFR mutations do not seem to play a role. Anti-EGFR therapies include monoclonal antibodies (eg, cetuximab and panitumumab) and receptor tyrosine kinase inhibitors (eg, erlotinib and gefitinib).

The results of a multicenter, open-label, randomized Phase III trial (EXPAND) testing the efficacy of cetuximab (Erbitux ${ }^{\mathrm{TM}}$, Merck KGaA, Darmstadt, Germany) in 
combination with cisplatin and capecitabine first line for patients with $69 \%$ advanced gastric adenocarcinoma and $31 \%$ adenocarcinoma of the gastroesophageal junction (GEJ) failed to show a significant improvement of PFS, when compared to cisplatin and capecitabine alone (Lordick et al, ${ }^{68}$ ESMO 2012). The EXPAND trial followed promising results from four Phase II trials. This first trial combined cetuximab with cisplatin and docetaxel (DOCETUX) in patients with locally advanced or metastatic gastric cancer $(82 \%)$ or GEJ tumors $(18 \%)$. It showed a disease control rate of $77 \%$ among 68 patients (Table 4). ${ }^{65}$ The second trial combined cetuximab with irinotecan and 5-FU in patients with locally advanced or metastatic gastric cancer $(71 \%)$ or GEJ tumors $(29 \%)$. It showed a disease control rate of $79 \%$ among 48 patients (Table 4). ${ }^{66}$ The third trial again combined cetuximab with irinotecan and 5-FU (FOLCETUX) in patients with locally advanced or metastatic gastric cancer (89\%) or GEJ tumors (11\%). It showed a disease control rate of $91 \%$ among 38 patients (Table 4). ${ }^{67}$ The fourth trial combined cetuximab with oxaliplatin and 5-FU in patients with locally advanced or \pm metastatic gastric cancer $(52 \%)$ or GEJ tumors $(48 \%)$. It showed a disease control rate of $83 \%$ among 52 patients (Table 4). ${ }^{68}$ Regarding patients with SCC, a combination of cetuximab and cisplatin/5-FU (CF) was compared with $\mathrm{CF}$ in a prospective randomized study. ${ }^{69}$ It was concluded that cetuximab can be safely combined with CF chemotherapy and may increase the efficacy of standard CF chemotherapy (Table 4). In contrast, the combination of another EGFRantibody panitumumab with EOX in patients with $\mathrm{AC}$, led to a decreased OS in comparison to EOX alone (Table 4). In this prospective Phase II/III UK study (NCT00824785, Randomized Trial of EOX \pm Panitumumab for Advanced and Locally Advanced Esophagogastric Cancer [REAL3]), ${ }^{70} 553$ patients with locally advanced AC of the esophagus and stomach cancer were recruited (Waddell et al, ASCO 2012, LBA4000). ${ }^{71}$ A combination with panitumumab, in comparison to EOX alone, was associated with increased $\mathrm{G} 3 / 4$ diarrhea (17\% versus $11 \%$ ), skin rash (14\% versus $1 \%)$, and thrombotic events (12\% versus $7 \%$ ), but less hematological toxicity ( $>$ G3 neutropenia 14\% versus $31 \%$ ). Interestingly, in the combination arm, OS was significantly improved in patients with G1-3 rash (median OS 10.2 versus 4.3 months $[P<0.001]$ ), with similar significant improvements seen in RR and PFS. Regarding study results for receptor tyrosine kinase inhibitors (eg, erlotinib and gefitinib), 5-FU/oxaliplatin (FOLFOX6) was tested in combination with erlotinib in 33 patients with metastatic or advanced AC of the esophagus and gastroesophageal junction, resulting in a sufficient RR and decent OS (Table 4). ${ }^{72}$

HER2R/NeuR (Human Epidermal Growth Factor Receptor 2, ERBB2R) is another member of the HER tyrosine kinase receptor family; overexpression in AC of the GEJ has been detected between $0 \%-43 \% .{ }^{73,74}$ Anti-HER2 therapies that have been evaluated in metastatic GEJ cancer are the monoclonal antibody trastuzumab and the oral small tyrosine kinase inhibitor lapatinib. Based on positive Phase II data in gastric cancer patients, trastuzumab was evaluated in a large Phase III trial, including gastric cancer patients and patients with AC of the GEJ if their tumors showed overexpression of HER2 protein by immunohistochemistry or gene amplification by fluorescence in situ hybridization. ${ }^{75}$ Participants were randomly assigned in a 1:1 ratio to receive capecitabine (or 5-FU)/cisplatin chemotherapy or chemotherapy in combination with intravenous trastuzumab. Since OS was significantly prolonged in the experimental group, trastuzumab in combination with chemotherapy can be considered as a new standard option for patients with HER2-positive advanced gastric or GEJ cancer (Table 4). Use of lapatinib, a dual EGFR and HER2R inhibitor, was associated with a lack of response in patients with GEJ cancer (Table 4). ${ }^{76}$ Currently, a combination with capecitabine/oxaliplatin (CapeOx) is being investigated (see Current investigations section).

Another principle of molecular-targeted therapy that has been studied in small patient groups is inhibition of vascular endothelial growth factor (VEGF), which is overexpressed in $30 \%-60 \%$ of patients with esophageal cancer. ${ }^{77-80}$ Since VEGF inhibition by bevacizumab (a humanized immunoglobulin [Ig] G1 antibody), in combination with cisplatin/irinotecan and docetaxel/oxaliplatin seemed promising, with a RR of $65 \%$ and $59 \%$, a Phase III study was initiated investigating a capecitabine/cisplatin combination \pm bevacizumab. ${ }^{81,82}$ Although 774 patients with inoperable, locally advanced, or metastatic stomach/GEJ AC with no prior therapy were randomized, no survival benefit could be detected for the targeted therapy (Avastin in Gastric Cancer [AVAGAST]-study, ASCO 2010, LBA 4007). ${ }^{83}$

Finally, oral multitarget tyrosine kinase inhibitors sunitinib, ${ }^{84}$ sorafenib, ${ }^{85}$ and protein kinase $\mathrm{C}$ inhibitor bryostatin- $1^{86,87}$ - have shown minor activity in GEJ AC.

\section{Palliative second-line treatment of esophageal cancer}

In case of treatment failure or relapse, second-line treatment may be indicated in patients who are still fit enough to tolerate 
Table 3 Prospective clinical trials of second-line chemotherapy of esophageal cancer

\begin{tabular}{|c|c|c|c|c|c|}
\hline Design & Treatment & $\mathbf{n}$ & $\mathbf{R R}$ & Median OS & Reference \\
\hline Phase II & Vinorelbine & $16^{+}$ & $6 \%$ & 6 months & 88 \\
\hline Phase II & Docetaxel & $\mathrm{II}^{++}$ & $0 \%$ & 4 months & 89 \\
\hline Phase II & Docetaxel/irinotecan & $24^{+++}$ & $12.5 \%$ & 6.5 months & 94 \\
\hline Phase II & Paclitaxel & $13^{+++}$ & $0 \%$ & NA & 91 \\
\hline Phase II & Docetaxel & $38^{+++}$ & $16 \%$ & 8.1 months & 90 \\
\hline Phase II & Docetaxel/capecitabine & $8^{+1+}$ & $25 \%$ & 6.2 months & 54 \\
\hline Phase II & Docetaxel/nedaplatin & $28^{+++}$ & $39.3 \%$ & 8.5 months & 100 \\
\hline Phase II & Docetaxel/nedaplatin & $12^{+}$ & $25 \%$ & NA & 97 \\
\hline Phase II & Irinotecan & $13^{++}$ & $15.4 \%$ & 5 months & 92 \\
\hline Phase II & Docetaxel/cisplatin/5-FU & $20^{+++}$ & $35 \%$ & 8 months & 101 \\
\hline Phase II & Docetaxel/cisplatin/5-FU & $32^{+++}$ & $50 \%$ & NA & 102 \\
\hline Phase II & Mitomycin/ifosfamide/cisplatin & $19^{+}$ & $12.5 \%$ & 5.2 months & 103 \\
\hline Phase II & Docetaxel/nedaplatin & $20^{+}$ & $25 \%$ & 6.5 months & 98 \\
\hline Phase II & Docetaxel/irinotecan & $15^{++}$ & $20 \%$ & II.4 months & 95 \\
\hline Phase II & Docetaxel/nedaplatin & $46^{+}$ & $27.1 \%$ & 5.9 months & 99 \\
\hline Phase II & Docetaxel/cisplatin & $35^{+}$ & $34.2 \%$ & 7.4 months & 96 \\
\hline \multirow[t]{2}{*}{ Phase III } & Docetaxel & $84^{\#}$ & $7 \% \#$ & 5.2 months $^{\#, *}$ & 93 \\
\hline & BSC & $84^{\#}$ & $0 \%$ & 3.6 months ${ }^{\#}$ & \\
\hline
\end{tabular}

Notes: $* P<0.05$; ${ }^{+}$squamous cell carcinoma; ${ }^{++}$adenocarcinoma; ${ }^{+++}$squamous cell carcinoma/adenocarcinoma; ${ }^{*}$ including stomach cancer.

Abbreviations: 5-FU, 5-fluorouracil; RR, response rate; OS, overall survival; NA, nonapplicable; BSC, best supportive care.

Table 4 Molecular-targeted therapy of esophageal cancer

\begin{tabular}{|c|c|c|c|c|c|}
\hline Design & Treatment & $\mathbf{n}$ & $\mathbf{R R}$ & Median OS & Reference \\
\hline Phase II (2nd line) & Erlotinib & $44^{++}$ & $9 \%$ & 6.7 months & 108 \\
\hline Phase II (2nd line) & Gefitinib & $36^{+++}$ & $3 \%$ & 5.5 months & 109 \\
\hline Phase II (Ist/2nd) & Gefitinib & $27^{++}$ & $11 \%$ & 4.5 months & 110 \\
\hline Phase II & Irinotecan/5-FU/cetuximab & $38^{++, \#}$ & $44 \%{ }^{\#}$ & 16 months $^{\#}$ & 67 \\
\hline \multirow[t]{2}{*}{ Phase II } & $\begin{array}{l}\text { Cisplatin/5-FU/ } \\
\text { cetuximab versus }\end{array}$ & $32^{+}$ & $19 \%$ & 9.5 months & 69 \\
\hline & cisplatin/5-FU & $30^{+}$ & $13 \%$ & 5.5 months & \\
\hline Phase II & Cisplatin/docetaxel/cetuximab & $13^{++}$ & $41 \% \#$ & 9 months & 65 \\
\hline Phase II & $\begin{array}{l}\text { Oxaliplatin/5-FU/ } \\
\text { cetuximab }\end{array}$ & $25^{++}$ & $77 \%$ & 9.5 months ${ }^{\#}$ & 68 \\
\hline Phase II (2nd line) & Cetuximab & $55^{++}$ & $6 \%$ & 4.0 months & 105 \\
\hline Phase III & $\begin{array}{l}\text { 5-FU (capecitabine) } / \\
\text { cisplatin } \pm \text { trastuzumab }\end{array}$ & $\begin{array}{l}58^{++} \\
48^{++}\end{array}$ & $\begin{array}{l}47 \% \# \\
35 \% \#\end{array}$ & $\begin{array}{l}13.8^{\#, * * *} \\
11 . I^{\#}\end{array}$ & 75 \\
\hline Phase II (2nd line) & $\begin{array}{l}\text { Cetuximab/ } \\
\text { irinotecan }\end{array}$ & $50^{++}$ & $14 \%$ & 5.5 months & 106 \\
\hline Phase II (2nd line) & Erlotinib & $\begin{array}{l}13^{+} \\
17^{++}\end{array}$ & $\begin{array}{l}15 \% \\
0 \%\end{array}$ & $\begin{array}{l}8.2 \text { months } \\
\text { II.2 months }\end{array}$ & 107 \\
\hline $\begin{array}{l}\text { Phase II } \\
\text { (2nd line) }\end{array}$ & Cetuximab & $35^{++}$ & $3 \%$ & 3.1 months & 104 \\
\hline Phase II & Irinotecan/5-FU/cetuximab & $13^{++}$ & $46 \%{ }^{\#}$ & I6.5 months $\#$ & 66 \\
\hline Phase II & 5-FU/oxaliplatin/erlotinib & $33^{++}$ & $52 \%$ & II.0 months & 72 \\
\hline Phase II/III & $\begin{array}{l}\text { Epirubicin/oxaliplatin/ } \\
\text { capecitabine } \pm \text { panitumumab }\end{array}$ & $\begin{array}{l}278^{\#} \\
275^{\#}\end{array}$ & $\begin{array}{l}46 \% \\
42 \%\end{array}$ & $\begin{array}{l}8.8 \text { months }^{\#} \\
11.3 \text { months }\end{array}$ & 71 \\
\hline Phase II & Lapatinib & $16^{++}$ & $6 \%$ & NA & 76 \\
\hline \multirow[t]{2}{*}{ Phase III (2nd line) } & Ramucirumab & $238^{+, \#}$ & $3.4 \%{ }^{\#}$ & 5.2 months $^{\# * * * *}$ & 111 \\
\hline & BSC & $117^{++, \#}$ & $2.6 \% \#$ & 3.8 months $\#$ & \\
\hline
\end{tabular}

Notes: $* * P<0.01 ;{ }^{+}$squamous cell carcinoma; + adenocarcinoma; ${ }^{+++}$squamous cell carcinoma/adenocarcinoma; "including gastric cancer patients.

Abbreviations: 5-FU, 5-fluorouracil; BSC, best supportive care; NA, non-applicable; RR, response rate; OS, overall survival. 
chemotherapy. These are approximately $40 \%$ of the patients who received first-line treatment. Unfortunately, currently there is only scarce data from prospective Phase II studies dealing with this group of patients.

\section{Single-agent chemotherapy}

Vinorelbine, ${ }^{88}$ docetaxel,${ }^{89,90}$ paclitaxel, ${ }^{91}$ and irinotecan ${ }^{92}$ were investigated as monotherapy (Table 3). Due to the low number of study participants and low RR in these studies, none of the substances could be recommended for secondline therapy. However, a recently presented randomized study (Cougar-02, Ford et al; ${ }^{93} 2013$ Gastrointestinal Cancers Symposium, LBA4) which compared docetaxel monotherapy with best supportive care in patients with stomach (46\%), GEJ (34\%), and esophageal cancer (20\%) demonstrated that docetaxel significantly improves OS (Table 3).

\section{Combination chemotherapy}

Taxane-based combinations were tested in several prospective Phase II trials, including a combination of docetaxel plus capecitabine, ${ }^{54}$ docetaxel plus irinotecan,,${ }^{94,95}$ docetaxel plus cisplatin, ${ }^{96}$ and docetaxel plus nedaplatin (Table 3). ${ }^{97-100}$ In the first three combination regimens, RR was still low, and the rate of hematologic toxicity high; eg, severe neutropenia occurred in almost $50 \%$ of the patients receiving docetaxel plus capecitabine. Although hematologic toxicity and nonhematologic toxicity were relatively low in the docetaxelplus-nedaplatin combination, these studies included only Asian patients, making it difficult to interpret these results for Caucasians. In addition, RR was still low. In view of the high activity of DCF-type regimens in first-line treatment, the combination of docetaxel, cisplatin, and 5-FU was investigated in the second-line setting as well. ${ }^{102}$ While dose reduction of all drugs in the first study resulted in lower RR, increased dose in the second study resulted in a remarkable hematologic toxicity. Finally, only a single non-taxane combination regimen consisting of mitomycin, ifosfamide, and cisplatin was tested. ${ }^{103}$ Although the toxicity rate was acceptable, the RR was low as well.

\section{Targeted therapy}

Cetuximab as second line treatment was studied either as monotherapy ${ }^{104,105}$ or in combination with irinotecan (Cetiri) in patients with AC (Table 4). ${ }^{106}$ In these studies, both RR and OS time were low. In contrast, there are contradictory results regarding erlotinib activity in $\mathrm{AC}$ as second-line monotherapy. ${ }^{107,108}$ Gefitinib as monotherapy in adenocarcinoma has shown only a minor activity. ${ }^{109,110}$ However, a recent prospectively randomized Phase III study was able to show that ramucirumab (RAM; IMC-1121B), ${ }^{111}$ a fully human immunoglobulin (Ig)G1 monoclonal antibody targeting VEGF-receptor (R) 2, significantly improves OS in patients with gastric and GEJ AC (REGARD, Fuchs et al; ${ }^{111} 2013$ Gastrointestinal Cancers Symposium, LBA5) (Table 4).

\section{Current investigations}

Regarding locally advanced esophageal cancer, several Phase III studies are now recruiting patients to investigate new chemotherapy combinations, such as S-1/cisplatin, S-1/paclitaxel, cisplatin/paclitaxel, and 5-FU/leucovorin/oxaliplatin/docetaxel (FLOT), as first-line treatment (Table 5). In addition, molecular-targeting compounds as combination partners, such as trastuzumab (monoclonal antibody against ErbB-2), lapatinib (dual EGFR and ErbB-2 tyrosine kinase inhibitor), and cetuximab (monoclonal antibody against EGFR), are studied, too (Table 5). Unfortunately, there is a paucity of Phase III trials investigating second- and third-line treatment. A UK study is currently testing gefitinib (EGFR tyrosine kinase inhibitor); a German study, paclitaxel/RAD 001 (everolimus, mTORinhibitor) combination (Table 5). At least four Phase III trials are investigating new combination partners for radiation in the neoadjuvant setting. Paclitaxel/carboplatin/radiation, paclitaxel/carboplatin/trastuzumab/radiation, navelbine/cisplatin/ radiation, and docetaxel/cisplatin/cetuximab/radiation are these regimens (Table 5). Inhibition of angiogenesis through the VEGF-inhibitor bevacizumab is another approach tested in the neoadjuvant setting. The UK-Study ST03 selects ECX as backbone chemotherapy combination partner (Table 5). Finally, improvement of definite chemoradiation for locally advanced disease is another focus of current research. Protonbeam therapy and intensity-modulated radiation therapy are both forms of radiation therapy designed to treat a specific area of the body while affecting as little of the surrounding normal tissue as possible. Proton-beam therapy is a newer technology designed to further reduce the amount of radiation that affects the surrounding normal tissue (Table 5). A particle accelerator is used during treatment to hit the tumor with a beam of protons. As a result, DNA damage of cells is induced by these charged particles, ultimately resulting in cell death or decrease of cell proliferation. Since tumors show a high rate of cell division and a reduced rate of cell repair, they are particularly vulnerable to attacks on DNA. Protons have little lateral side scatter in the tissue, due to their relatively 
Table 5 Ongoing/recruiting major Phase III clinical trials in esophageal cancer (according to ClinicalTrials.gov)

\begin{tabular}{|c|c|c|}
\hline Name & Drug & Indication \\
\hline BO27798 & Capecitabine/cisplatin $(X P) \pm$ trastuzumab & Locally advanced $A C$ and stomach cancer \\
\hline \multicolumn{3}{|l|}{ (NCT0I450696) } \\
\hline \multicolumn{3}{|l|}{ Worldwide } \\
\hline LOGiC & Capecitabine/oxaliplatin $(\mathrm{CapeOx}) \pm$ lapatinib & Locally advanced $\mathrm{AC}$ and stomach cancer \\
\hline \multicolumn{3}{|l|}{ (NCT0068090I) } \\
\hline \multicolumn{3}{|l|}{ Worldwide } \\
\hline POWER & Cisplatin/5-FU \pm panitumumab & Locally advanced SCC \\
\hline \multicolumn{3}{|l|}{ (NCT0I627379) } \\
\hline \multicolumn{3}{|l|}{ Germany } \\
\hline NCT00678535 & Capecitabine/cisplatin $(\mathrm{XP}) \pm$ cetuximab & Locally advanced $A C$ and stomach cancer \\
\hline \multicolumn{3}{|l|}{ Worldwide } \\
\hline DIGEST & $\mathrm{S}$ - I/cisplatin versus 5 -FU/cisplatin & Locally advanced $A C$ and stomach cancer \\
\hline \multicolumn{3}{|l|}{ (NCTOI285557) } \\
\hline \multicolumn{3}{|l|}{ Worldwide } \\
\hline NCT0I704690 & S-I/paclitaxel versus cisplatin/paclitaxel & Locally advanced SCC or AC \\
\hline China & versus 5 -FU/cisplatin & \\
\hline FLOT-4 & 5-FU/leucovorin/oxaliplatin/ & Locally advanced $\mathrm{AC}$ and stomach cancer \\
\hline (AIO-STO-02I0) & docetaxel (FLOT) versus epirubicin/ & \\
\hline Germany & cisplatin/5-FU (ECF) & \\
\hline OXFORD-COG (NCTOI243398) & Gefitinib & 2nd-line therapy for SCC or AC \\
\hline \multicolumn{3}{|l|}{ UK } \\
\hline AIO STO-0III & Paclitaxel + RAD00I (everolimus) & 2nd- and 3rd-line therapy for AC and \\
\hline (NCT0I248403) & & stomach cancer \\
\hline \multicolumn{3}{|l|}{ Germany } \\
\hline ICORG I0-I4 & Paclitaxel/carboplatin/radiation (CROSS protocol) & Resectable, locally advanced AC \\
\hline (NCT0I726452) & (neoadjuvant) versus epirubicin/cisplatin/5-FU & \\
\hline Ireland & (ECF, MAGIC protocol) (neo- and adjuvant) & \\
\hline NCT0I 216527 & Navelbine/cisplatin/radiation (neoadjuvant) & Resectable, locally advanced SCC \\
\hline China & versus surgery alone & \\
\hline SAKK 75/08 (NCTOII07639) & Docetaxel/cisplatin/cetuximab/radiation & Resectable, locally advanced SCC or AC \\
\hline Europe & (neoadjuvant) \pm cetuximab (adjuvant) & \\
\hline RTOG-1010 & Paclitaxel/carboplatin/radiation \pm trastuzumab & Resectable, locally advanced AC \\
\hline (NCT0II96390) & (neoadjuvant) + trastuzumab (adjuvant) & \\
\hline \multicolumn{3}{|c|}{ 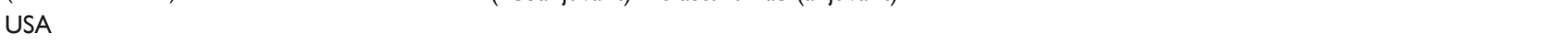 } \\
\hline ST03 & Epirubicin/cisplatin/capecitabine $(E C X) \pm$ bevacizumab & Resectable, locally advanced AC \\
\hline (NCT00450203) & (neoadjuvant and adjuvant) & \\
\hline \multicolumn{3}{|l|}{ UK } \\
\hline NCT0I5I 2589 & Radiation $(\mathrm{PBT}) \pm \mathrm{CT}$ versus radiation $(\mathrm{IMRT}) \pm \mathrm{CT}$ & Potentially resectable or unresectable \\
\hline USA & & $S C C$ or $A C$ \\
\hline FRE-FNCLCC-ACCORD-17-0707 & FOLFOX/radiation versus cisplatin/5-FU/radiation & Locally advanced SCC or AC \\
\hline \multicolumn{3}{|l|}{ (NCT00861094) } \\
\hline \multicolumn{3}{|l|}{ France } \\
\hline ESO20I2-0I (NCTOI59II35) & Paclitaxel/5-FU/radiation versus cisplatin/ & Locally advanced SCC \\
\hline China & 5-FU/radiation & \\
\hline CONCORDE & FOLFOX-4/radiation (50 Gy) versus & Locally advanced SCC or AC \\
\hline (NCT0I3482I7) & FOLFOX-4/ radiation (66 Gy) & \\
\hline \multicolumn{3}{|l|}{ France } \\
\hline RTOG-0436 (NCT00655876) & Paclitaxel/cisplatin/radiation \pm cetuximab & Locally advanced SCC or AC \\
\hline \multicolumn{3}{|c|}{ a } \\
\hline ESCC-307PLAH-XJM (NCTOI752205) & Paclitaxel/radiation \pm erlotinib & Locally advanced SCC \\
\hline \multicolumn{3}{|l|}{ China } \\
\hline Shixiu - I & Paclitaxel/cisplatin/radiation \pm erlotinib & Locally advanced SCC or AC \\
\hline \multicolumn{3}{|l|}{ (NCT00686II4) } \\
\hline China & & \\
\hline
\end{tabular}


large mass. The beam stays focused on the tumor shape, does not broaden much, and causes only low-dose side effects to surrounding tissue. Intensity-modulated radiation therapy, which is less expensive, comprises an advanced mode of high-precision radiotherapy that uses computer-controlled linear accelerators (3-D computed tomography or magnetic resonance images are used for planning) to deliver precise radiation doses to a malignant tumor or specific areas within the tumor. The radiation dose can be more precisely adjusted to the 3-D shape of the tumor by modulating - or controlling the intensity of the radiation beam in multiple small volumes. Using intensity-modulated radiation therapy, higher radiation doses, and combinations of multiple intensity-modulated fields coming from different beam directions can be focused to regions within the tumor, while the dose to surrounding normal critical structures can be minimized.

FOLFOX, paclitaxel/5-FU, and paclitaxel/cisplatin are potential combination partners for small molecular-targeting compounds cetuximab or erlotinib (Table 5).

\section{Summary}

Diagnosis and therapy of esophageal cancer is an interdisciplinary challenge. Exact staging is a prerequisite for optimized and individualized therapy planning. Neoadjuvant chemotherapy, now available in different combinations, should be provided to patients with locally advanced adenocarcinoma. Alternatively, there is now sufficient evidence that these patients might undergo neoadjuvant chemoradiation, too. In contrast, patients with locally advanced squamous cell carcinoma are more likely to benefit from neoadjuvant chemoradiation than from chemotherapy alone; however, there is a lack of randomized studies comparing both modalities. In general, postoperative complication and mortality rate are higher after chemoradiation than chemotherapy alone. Definitive chemoradiation has been shown to be effective in selected patients with squamous cell carcinoma (data for adenocarcinoma are scarce). In the palliative situation, combination chemotherapy with two drugs has been shown to be effective, both in patients with adenoand squamous cell carcinoma. Effectiveness can be further increased with a triple combination in patients with adenocarcinoma, at the cost of increased side effects. Addition of monoclonal antibody trastuzumab in HER2 positive metastatic gastroesophageal junction cancer increases OS even further. Second-line therapy after failure of first-line therapy or tumor recurrence is still experimental, but docetaxel monotherapy, and targeting VEGF-R2 with ramucirumab have improved OS, according to two separate Phase III studies. In the past, many different predictors for response of AC/SCC to chemotherapy/ chemoradiation have been investigated, ranging from simple histology to various molecular markers, such as p53, proliferative cell nuclear antigen, EGFR, Ki-67, cyclin D1, expression of thymidylate synthase, and microvessel density, in both tissue and serum. None are reliable, and results cannot help clinical decision making. Metabolic imaging with positronemission tomography scanning is promising, with its ability to predict response early in the course of treatment. ${ }^{112}$ Therefore, definition of predictive and prognostic factors, optimization of chemo- and chemoradiation regimens and evaluation of the role of molecular-targeted therapy are the goal of current studies. One major limitation to cancer therapies results from the heterogeneity of the cancer cells even within a single tumor. As tumors increase in size, many cancer cells grow distant from the blood supply, which may cause them to divide less frequently than others in the population. In addition, with increasing numbers of cancer cells, there is an increase in genetic mutations with each generation that will help cancer cells to escape the toxicity of treatment. It is, therefore, a big challenge to target these treatment-resistant cancer cells that are responsible for disease recurrence. The combination of therapeutic regimens that target different mechanisms of cancer cell development to provide the maximal cell killing without increasing toxic side effects to the patient is, therefore, mandatory.

\section{Disclosure}

The authors report no conflicts of interest in this work.

\section{References}

1. Wittekind C, Meyer HJ. Ösophagus einschließlich ösophagogastraler Übergang [Esophagus including esophagogastric junction]. In: TNMKlassifikation Maligner Tumoren 2010, 7th ed. Leipzig, Germany: Springer-Verlag. 2010;63-68.

2. Mawhinney MR, Glasgow RE. Current treatment options for the management of esophageal cancer. Cancer Manag Res. 2012;4:367-377.

3. Sjoquist KM, Burmeister BH, Smithers BM, et al. Survival after neoadjuvant chemotherapy or chemoradiotherapy for resectable esophageal carcinoma: an updated meta-analysis. Lancet Oncol. 2011;12(7): 681-692.

4. Ando N, Kato H, Igaki H, et al. A randomized trial comparing postoperative adjuvant chemotherapy with cisplatin and 5-FU versus preoperative chemotherapy for localized advanced squamous cell carcinoma of the thoracic esophagus (JCOG9907). Ann Surg Oncol. 2012;19(1):68-74.

5. Cunningham D, Allum WH, Stenning SP, et al. Perioperative chemotherapy versus surgery alone for resectable gastroesophageal cancer. $N$ Engl J Med. 2006;355(1):11-20.

6. Ychou M, Boige V, Pignon JP, et al. Perioperative chemotherapy compared with surgery alone for resectable gastresophageal adenocarcinoma: an FNCLCC and FFCD multicenter phase III trial. J Clin Oncol. 2011;29(13):1715-1721.

7. Thuss-Patience PC, Hofheinz RD, Arnold D, et al. Perioperative chemotherapy with docetaxel, cisplatin, and capecitabine (DCX) in gastroesophageal adenocarcinoma: a phase II study of the Arbeitsgemeinschaft Internistische Onkologie (AIO). Ann Oncol. 2012;23(11):2827-2834. 
8. Ferri LE, Ades S, Alcindor T, et al. Perioperative docetaxel, cisplatin, and 5-FU (DCF) for locally advanced esophageal and gastric adenocarcinoma: a multicenter phase II trial. Ann Oncol. 2012;23(6): 1512-1517.

9. Idelevich E, Kashtan H, Klein Y, et al. Prospective phase II study of neoadjuvant therapy with cisplatin, 5-FU, and bevacizumab for locally advanced resectable esophageal cancer. Onkologie. 2012;35(7-8): 427-431.

10. Macdonald JS, Smalley SR, Benedetti J, et al. Chemoradiotherapy after surgery compared with surgery alone for adenocarcinoma of the stomach or gastroesophageal junction. N Engl J Med. 2001;345(10): 725-730.

11. Smalley SR, Benedetti JK, Haller DG, et al. Updated analysis of SWOG-directed intergroup study 0116: a phase III trial of adjuvant radiochemotherapy versus observation after curative gastric cancer resection. J Clin Oncol. 2012;30(19):2327-2333.

12. Kofoed SC, Muhic A, Baeksgaard L, et al. Survival after adjuvant chemoradiotherapy or surgery alone in resectable adenocarcinoma at the gastroesophageal junction. Scand J Surg. 2012;101(1):26-31.

13. Leichman LP, Goldman BH, Bohanes PO, et al. S0356: a phase II clinical and prospective molecular trial with oxaliplatin, fluorouracil, and external-beam radiation therapy before surgery for patients with esophageal adenocarcinoma. J Clin Oncol. 2011;29(34): 4555-4560.

14. Ilson DH, Minsky BD, Ku GY, et al. Phase 2 trial of induction and concurrent chemoradiotherapy with weekly irinotecan and cisplatin followed by surgery for esophageal cancer. Cancer. 2012;118(11):2820-2827.

15. Pasini F, de Manzoni G, Zanoni A, et al. Neoadjuvant therapy with weekly docetaxel and cisplatin, 5-FU continuous infusion, and concurrent radiotherapy in patients with locally advanced esophageal cancer produced a high percentage of long-lasting pathological complete response: a phase 2 study. Cancer. 2013;119(5):939-945.

16. van Hagen P, Hulshof MC, van Lanschot JJ, et al. Preoperative chemoradiotherapy for esophageal or junctional cancer. $N$ Engl J Med. 2012;366(22):2074-2084.

17. Jin HL, Zhu H, Ling TS, Zhang HJ, Shi RH. Neoadjuvant chemoradiotherapy for resectable esophageal carcinoma: a meta-analysis. World $J$ Gastroenterol. 2009;15(47):5983-5991.

18. Nygaard K, Hagen S, Hansen HS, et al. Preoperative radiotherapy prolongs survival in operable esophageal carcinoma: a randomized multicenter study of preoperative radiotherapy and chemotherapy. The second Scandinavian trial in esophageal cancer. World J Surg. 1992; 16(6):1104-1109.

19. Apinop C, Puttisak P, Preecha N. A prospective study of combined therapy in esophageal cancer. Hepatogastroenterology. 1994;41(4): 391-393.

20. Le Prise E, Etienne PL, Meunier B, et al. A randomized study of chemotherapy, radiation therapy, and surgery versus surgery for localized squamous cell carcinoma of the esophagus. Cancer. 1994;73(7): 1779-1784.

21. Walsh TN, Noonan N, Hollywood D, Kelly A, Keeling N, Hennessy TP. A comparison of multimodal therapy and surgery for esophageal adenocarcinoma. $N$ Engl J Med. 1996;335(7):462-467.

22. Bosset JF, Gignoux M, Triboulet JP, et al. Chemoradiotherapy followed by surgery compared with surgery alone in squamous-cell cancer of the esophagus. N Engl J Med. 1997;337(3):161-167.

23. Urba SG, Orringer MB, Turrisi A, Iannettoni M, Forastiere A, Strawderman M. Randomized trial of preoperative chemoradiation versus surgery alone in patients with locoregional esophageal carcinoma. J Clin Oncol. 2001;19(2):305-313.

24. Lee JL, Park SI, Kim SB, et al. A single institutional phase III trial of preoperative chemotherapy with hyperfractionation radiotherapy plus surgery versus surgery alone for resectable esophageal squamous cell carcinoma. Ann Oncol. 2004;15(6):947-954.

25. Burmeister BH, Smithers BM, Gebski V, et al. Surgery alone versus chemoradiotherapy followed by surgery for resectable cancer of the esophagus: a randomized-controlled phase III trial. Lancet Oncol. 2005;6(9):659-668.
26. Tepper J, Krasna MJ, Niedzwiecki D, et al. Phase III trial of trimodality therapy with cisplatin, fluorouracil, radiotherapy, and surgery compared with surgery alone for esophageal cancer: CALGB 9781. J Clin Oncol. 2008;26(7):1086-1092.

27. An FS, Huang JQ, Xie YT, Chen SH, Rong TH. [A prospective study of combined chemoradiotherapy followed by surgery in the treatment of esophageal carcinoma.] Zhonghua Zhong Liu Za Zhi. 2003;25(4): 376-379. Chinese. [with English abstract].

28. Natsugoe S, Okumura H, Matsumoto M, et al. Randomized-controlled study on preoperative chemoradiotherapy followed by surgery versus surgery alone for esophageal squamous cell cancer in a single institution. Dis Esophagus. 2006;19(6):468-472.

29. Lv J, Cao XF, Zhu B, Ji L, Tao L, Wang DD. Long-term efficacy of perioperative chemoradiotherapy on esophageal squamous cell carcinoma. World J Gastroenterol. 2010;16(13):1649-1654.

30. Mariette C, Seitz JF, Maillard E, et al. Surgery alone versus chemoradiotherapy followed by surgery for localized esophageal cancer: analysis of a randomized-controlled trial FFCD 9901. J Clin Oncol. 2010;28(Suppl 15):4005.

31. Bendell JC, Meluch A, Peyton J, et al. A phase II trial of preoperative concurrent chemotherapy/radiation therapy plus bevacizumab/erlotinib in the treatment of localized esophageal cancer. Clin Adv Hematol Oncol. 2012;10(7):430-437.

32. Cooper JS, Guo MD, Herskovic A, et al. Chemoradiotherapy of locally advanced esophageal cancer: long-term follow-up of a prospective randomized trial (RTOG 85-01). Radiation Therapy Oncology Group. JAMA. 1999;281(17):1623-1627.

33. Stahl M, Stuschke M, Lehmann N, et al. Chemoradiation with and without surgery in patients with locally advanced squamous cell carcinoma of the esophagus. J Clin Oncol. 2005;23(10):2310-2317.

34. Bedenne L, et al. Chemoradiation followed by surgery compared with chemoradiation alone in squamous cancer of the esophagus: FFCD 9102. J Clin Oncol. 2007;25:1160-1168.

35. Teoh AY, Chiu PW, Yeung WK, Liu SY, Wong SK, Ng EK, et al. Long-term survival outcomes after definitive chemoradiation versus surgery in patients with resectable squamous carcinoma of the esophagus: results from a randomized-controlled trial. Ann Oncol. 2013;24(1): $165-171$.

36. Conroy T, Galais MP, Raoul JL, et al. Phase Ill randomized trial of definitive chemoradiotherapy (CRT) with FOLFOX or cisplatin and fluorouracil in esophageal cancer (EC): Final results of the PRODIGE 5/ACCORD 17 trial. J Clin Oncol. 2012;30

37. Crosby T, Hurt C, Falk S, et al. SCOPE 1:A phase 11/111 trial of chemoradiotherapy in esophageal cancer plus or minus cetuximab. J Clin Oncol. 2012;30.

38. Shim HJ, Kim DE, Hwang JE, et al. A phase II study of concurrent chemoradiotherapy with weekly docetaxel and cisplatin in advanced esophageal cancer. Cancer Chemother Pharmacol. 2012;70(5): 683-690.

39. Kranzfelder M, Schuster T, Geinitz H, Friess H, Büchler P. Meta-analysis of neoadjuvant treatment modalities and definitive nonsurgical therapy for esophageal squamous cell cancer. $\mathrm{Br} J \mathrm{Surg}$. 2011;98(6):768-783.

40. Yoon MS, Nam TK, Lee JS, et al. VEGF as a predictor for response to definitive chemoradiotherapy and COX-2 as a prognosticator for survival in esophageal squamous cell carcinoma. J Korean Med Sci. 2011;26(4):513-520.

41. Bleiberg H, Conroy T, Paillot B, et al. Randomized phase II study of cisplatin and 5-FU (5-FU) versus cisplatin alone in advanced squamous cell esophageal cancer. Eur J Cancer. 1997;33(8):1216-1220.

42. Ajani JA, Rodriguez W, Bodoky G, et al. Multicenter phase III comparison of cisplatin/S-1 with cisplatin/infusional fluorouracil in advanced gastric or gastroesophageal adenocarcinoma study: the FLAGS trial. $J$ Clin Oncol. 2010;28(9):1547-1553.

43. Lee J, Im YH, Cho EY, et al. A phase II study of capecitabine and cisplatin (XP) as first-line chemotherapy in patients with advanced esophageal squamous cell carcinoma. Cancer Chemother Pharmacol. 2008;62(1):77-84 
44. Mauer AM, Kraut EH, Krauss SA, et al. Phase II trial of oxaliplatin, leucovorin, and fluorouracil in patients with advanced carcinoma of the esophagus. Ann Oncol. 2005;16(8):1320-1325.

45. van Meerten E, Eskens FA, van Gameren EC, et al. First-line treatment with oxaliplatin and capecitabine in patients with advanced or metastatic esophageal cancer: a phase II study. Br J Cancer. 2007;96(9): 1348-1352.

46. Jatoi A, Murphy BR, Foster NR, et al. Oxaliplatin and capecitabine in patients with metastatic adenocarcinoma of the esophagus, gastroesophageal junction and gastric cardia: a phase II study from the North Central Cancer Treatment Group. Ann Oncol. 2006;17(1): 29-34.

47. Al-Batran SE, Hartmann JT, Probst S, et al. Phase III trial in metastatic gastroesophageal adenocarcinoma with fluorouracil, leucovorin plus either oxaliplatin or cisplatin: a study of the Arbeitsgemeinschaft Internistische Onkologie. J Clin Oncol. 2008; 26(9):1435-1442.

48. Zhang X, Shen L, Li J, Li Y, Li J, Jin M. A phase II trial of paclitaxel and cisplatin in patients with advanced squamous-cell carcinoma of the esophagus. Am J Clin Oncol. 2008;31(1):29-33.

49. 1lson DH, Ajani J, Shalla K, et al. Phase II trial of paclitaxel, fluorouracil, and cisplatin in patients with advanced carcinoma of the esophagus. J Clin Oncol. 1998;16:1826-1834.

50. 1lson DH, Saltz L, Enzinger P, et al. Phase II trial of weekly irinotecan plus cisplatin in advanced esophagea 1 cancer. J Clin Oncol. 1999;17: 3270-3275.

51. Conroy T, Etienne PL, Adenis A, et al. Vinorelbine and cisplatin in metastatic squamous cell carcinoma of the oesophagus: response, toxicity, quality of life and survival. Ann Oncol. 2002;13:721-729.

52. Yun T, Han JY, Lee JS, et al. Phase II study of weekly paclitaxel and capecitabine in patients with metastatic or recurrent esophageal squamous cell carcinoma. BMC Cancer. 2011;11:385.

53. Giordano KF, Jatoi A, Stella PJ, et al. Docetaxel and capecitabine in patients with metastatic adenocarcinoma of the stomach and gastroesophageal junction: a Phase II study from the North Central Cancer Treatment Group. Ann Oncol. 2006;17(4):652-656.

54. Lorenzen S, Duyster J, Lersch C, et al. Capecitabine plus docetaxel every 3 weeks in first- and second-line metastatic esophageal cancer: final results of a phase II trial. Br J Cancer. 2005;92(12): 2129-2133.

55. Cunningham D, Starling N, Rao S, et al. Capecitabine and oxaliplatin for advanced esophagogastric cancer. $N$ Engl J Med. 2008;358(1): 36-46.

56. Ajani JA, Fodor MB, Tjulandin SA, et al. Phase II multi-institutional randomized trial of docetaxel plus cisplatin with or without fluorouracil in patients with untreated, advanced gastric, or gastroesophageal adenocarcinoma. J Clin Oncol. 2005;23(24):5660-5667.

57. Lorenzen S, Hentrich M, Haberl C, et al. Split-dose docetaxel, cisplatin, and leucovorin/fluorouracil as first-line therapy in advanced gastric cancer and adenocarcinoma of the gastroesophageal junction: results of a phase II trial. Ann Oncol. 2007;18(10):1673-1679.

58. Evans D, Miner T, Iannitti D, et al. Docetaxel, capecitabine, and carboplatin in metastatic esophagogastric cancer: a phase II study. Cancer Invest. 2007;25(6):445-448.

59. Tebbutt NC, Cummins MM, Sourjina T, et al. Randomized, noncomparative phase II study of weekly docetaxel with cisplatin and 5-FU or with capecitabine in esophagogastric cancer: the AGITG ATTAX trial. Br J Cancer. 2010;102(3):475-481.

60. Huang J, Zhou Y, Zhang H, et al. A phase II study of biweekly paclitaxel and cisplatin chemotherapy for recurrent or metastatic esophageal squamous cell carcinoma: ERCC1 expression predicts response to chemotherapy. Med Oncol. 2013;30:343.

61. Itakura Y, Sasano H, Shiga C, et al. Epidermal growth factor receptor overexpression in esophageal carcinoma. An immunohistochemical study correlated with clinicopathologic findings and DNA amplification. Cancer. 1994;74(3):795-804.
62. Kitagawa Y, Ueda M, Ando N, et al. Further evidence for prognostic significance of epidermal growth factor receptor gene amplification in patients with esophageal squamous cell carcinoma. Clin Cancer Res. 1996;2(5):909-914.

63. Gibault L, Metges JP, Conan-Charlet V, et al. Diffuse EGFR staining is associated with reduced overall survival in locally advanced esophageal squamous cell cancer. Br J Cancer. 2005;93(1):107-115.

64. Wilkinson NW, Black JD, Roukhadze E, et al. Epidermal growth factor receptor expression correlates with histologic grade in resected esophageal adenocarcinoma. J Gastrointest Surg. 2004;8(4):448-453.

65. Pinto C, Di Fabio F, Barone C, et al. Phase II study of cetuximab in combination with cisplatin and docetaxel in patients with untreated advanced gastric or gastroesophageal junction adenocarcinoma (DOCETUX study). Br J Cancer. 2009;101(8):1261-1268.

66. Moehler M, Mueller A, Trarbach T, et al. Cetuximab with irinotecan, folinic acid, and 5-FU as first-line treatment in advanced gastroesophageal cancer: a prospective multicenter biomarker-oriented phase II study. Ann Oncol. 2011;22(6):1358-1366.

67. Pinto C, Di Fabio F, Siena S, et al. Phase II study of cetuximab in combination with FOLFIRI in patients with untreated advanced gastric or gastroesophageal junction adenocarcinoma (FOLCETUX study). Ann Oncol. 2007;18(3):510-517.

68. Lordick F, Luber B, Lorenzen S, et al. Cetuximab plus oxaliplatin/ leucovorin/5-FU in first-line metastatic gastric cancer: a phase II study of the Arbeitsgemeinschaft Internistische Onkologie (AIO). Br J Cancer. 2010;102(3):500-505.

69. Lorenzen S, Schuster T, Porschen R, et al. Cetuximab plus cisplatin5-FU versus cisplatin-5-FU alone in first-line metastatic squamous cell carcinoma of the esophagus: a randomized phase II study of the Arbeitsgemeinschaft Internistische Onkologie. Ann Oncol. 2009;20(10):1667-1673.

70. Okines AF, Ashley SE, Cunningham D, et al. Epirubicin, oxaliplatin, and capecitabine with or without panitumumab for advanced esophagogastric cancer: dose-finding study for the prospective multicenter, randomized, phase II/III REAL-3 trial. J Clin Oncol. 2010;28(25):3945-3950.

71. Waddell TS, Chau I, Barbachano Y, et al. A randomized multicenter trial of epirubicin, oxaliplatin, and capecitabine (EOC) plus panitumumab in advanced esophagogastric cancer (REAL3). J Clin Oncol. 2012;30.

72. Wainberg ZA, Lin LS, DiCarlo B, et al. Phase II trial of modified FOLFOX6 and erlotinib in patients with metastatic or advanced adenocarcinoma of the esophagus and gastroesophageal junction. $\mathrm{BrJ}$ Cancer. 2011;105(6):760-765.

73. al-Kasspooles M, Moore JH, Orringer MB, Beer DG. Amplification and over-expression of the EGFR and erbB-2 genes in human esophageal adenocarcinomas. Int J Cancer. 1993;54(2):213-219.

74. Ross JS, McKenna BJ. The HER-2/neu oncogene in tumors of the gastrointestinal tract. Cancer Invest. 2001;19(5):554-568.

75. Bang YJ, Van Cutsem E, Feyereislova A, et al. Trastuzumab in combination with chemotherapy versus chemotherapy alone for treatment of HER2-positive advanced gastric or gastroesophageal junction cancer (ToGA): a Phase 3, open-label, randomized-controlled trial. Lancet. 2010;376(9742):687-697.

76. Galsky MD, Von Hoff DD, Neubauer M, et al. Target-specific, histology-independent, randomized discontinuation study of lapatinib in patients with HER2-amplified solid tumors. Invest New Drugs. 2012;30(2):695-701.

77. Inoue K, Ozeki Y, Suganuma T, Sugiura Y, Tanaka S. Vascular endothelial growth factor expression in primary esophageal squamous cell carcinoma. Association with angiogenesis and tumor progression. Cancer. 1997;79(2):206-213.

78. Kitadai Y, Haruma K, Tokutomi T, et al. Significance of vessel count and vascular endothelial growth factor in human esophageal carcinomas. Clin Cancer Res. 1998;4(9):2195-2200.

79. Kleespies A, Guba M, Jauch KW, Bruns CJ, et al. Vascular endothelial growth factor in esophageal cancer. J Surg Oncol. 2004;87(2): 95-104. 
80. Shih CH, Ozawa S, Ando N, Ueda M, Kitajima M. Vascular endothelial growth factor expression predicts outcome and lymph node metastasis in squamous cell carcinoma of the esophagus. Clin Cancer Res. 2000;6(3):1161-1168.

81. Shah MA, Ramanathan RK, Ilson DH, et al. Multicenter phase II study of irinotecan, cisplatin, and bevacizumab in patients with metastatic gastric or gastroesophageal junction adenocarcinoma. $J$ Clin Oncol. 2006;24(33):5201-5206

82. El-Rayes BF, Zalupski M, Bekai-Saab T, et al. A phase II study of bevacizumab, oxaliplatin, and docetaxel in locally advanced and metastatic gastric and gastroesophageal junction cancers. Ann Oncol. 2009;21(10):1999-2004

83. Kang Y, Ohtsu A, Van Cutsem E, et al. AVAGAST: A randomized, double-blind, placebo controlled, phase Ill study of first-line capecitabine and cisplatin plus bevacizumab or placebo in patients with advanced gastric cancer (AGC). J Clin Oncol. 2010;28:18s.

84. Bang YJ, Kang YK, Kang WK, et al. Phase II study of sunitinib as second-line treatment for advanced gastric cancer. Invest New Drugs. 2011;29(6):1449-1458.

85. Sun W, Powell M, O’Dwyer PJ, Catalano P, Ansari RH, Benson AB 3rd. Phase II study of sorafenib in combination with docetaxel and cisplatin in the treatment of metastatic or advanced gastric and gastroesophageal junction adenocarcinoma: ECOG 5203. J Clin Oncol. 2010; 28(18):2947-2951.

86. Ku GY, Ilson DH, Schwartz LH, et al. Phase II trial of sequential paclitaxel and $1 \mathrm{~h}$ infusion of bryostatin-1 in patients with advanced esophageal cancer. Cancer Chemother Pharmacol. 2008;62(5): 875-880.

87. Ajani JA, Jiang Y, Faust J, et al. A multicenter phase II study of sequential paclitaxel and bryostatin-1 (NSC 339555) in patients with untreated, advanced gastric, or gastroesophageal junction adenocarcinoma Invest New Drugs. 2006;24(4):353-357.

88. Conroy T, Etienne PL, Adenis A, et al. Phase II trial of vinorelbine in metastatic squamous cell esophageal carcinoma. European Organization for Research and Treatment of Cancer Gastrointestinal Treat Cancer Cooperative Group. J Clin Oncol. 1996;14(1):164-170.

89. Heath EI, Urba S, Marshall J, Piantadosi S, Forastiere AA. Phase II trial of docetaxel chemotherapy in patients with incurable adenocarcinoma of the esophagus. Invest New Drugs. 2002;20(1):95-99.

90. Muro K, Hamaguchi T, Ohtsu A, et al. A phase II study of single-agent docetaxel in patients with metastatic esophageal cancer. Ann Oncol. 2004;15(6):955-959.

91. Anderson SE, O'Reilly EM, Kelsen DP, Ilson DH. Phase II trial of 96-hour paclitaxel in previously treated patients with advanced esophageal cancer. Cancer Invest. 2003;21(4):512-516.

92. Burkart C, Bokemeyer C, Klump B, Pereira P, Teichmann R, Hartmann JT. A Phase II trial of weekly irinotecan in cisplatin-refractory esophageal cancer. Anticancer Res. 2007;27(4C):2845-2848.

93. Ford H, Marshall A, Wadsley J, et al. Cougar-02: A randomized phase Ill study of docetaxel versus active symptom control in advanced esophagogastric adenocarcinoma. J Clin Oncol. 2012;30.

94. Lordick F, von Schilling C, Bernhard H, Hennig M, Bredenkamp R, Peschel C. Phase II trial of irinotecan plus docetaxel in cisplatinpretreated relapsed or refractory esophageal cancer. $B r J$ Cancer. 2003;89(4):630-633.

95. Burtness B, Gibson M, Egleston B, et al. Phase II trial of docetaxelirinotecan combination in advanced esophageal cancer. Ann Oncol. 2009;20(7):1242-1248.

96. Shim HJ, Cho SH, Hwang JE, et al. Phase II study of docetaxel and cisplatin chemotherapy in 5-FU/cisplatin pretreated esophageal cancer. Am J Clin Oncol. 2010;33(6):624-628.

97. Yoshioka T, Sakayori M, Kato S, et al. Dose escalation study of docetaxel and nedaplatin in patients with relapsed or refractory squamous cell carcinoma of the esophagus pretreated using cisplatin, 5-FU, and radiation. Int J Clin Oncol. 2006;11(6):454-460.
98. Nakajima Y, Suzuki T, Haruki S, et al. A pilot trial of docetaxel and nedaplatin in cisplatin-pretreated relapsed or refractory esophageal squamous cell cancer. Hepatogastroenterology. 2008;55(86-87): $1631-1635$.

99. Jin J, Xu X, Wang F, et al. Second-line combination chemotherapy with docetaxel and nedaplatin for Cisplatin-pretreated refractory metastatic/recurrent esophageal squamous cell carcinoma. $J$ Thorac Oncol. 2009;4(8):1017-1021.

100. Osaka Y, Takagi Y, Hoshino S, Tachibana S, Tsuchida A, Aoki T. Combination chemotherapy with docetaxel and nedaplatin for recurrent esophageal cancer in an outpatient setting. Dis Esophagus. 2006; 19(6):473-476.

101. Tanaka T, Fujita H, Sueyoshi S, et al. Second-line combination chemotherapy with docetaxel for cisplatin-pretreated refractory metastatic esophageal cancer: a preliminary report of initial experience. Chemotherapy. 2007;53:449-453.

102. Minamide J, Aoyama N, Takada K, Oota Y. [Evaluation of docetaxel, CDDP, and 5-FU combined therapy as second-line chemotherapy for esophagus cancer.] Gan To Kagaku Ryoho. 2007;34(1):49-52. Japanese [with English abstract].

103. Park BB, Im YH, Hwang IG, et al. Salvage chemotherapy with mitomycin C, ifosfamide, and cisplatin (MIC) for previously treated metastatic or recurrent esophageal squamous cell carcinoma. Invest New Drugs. 2008;26(4):387-392.

104. Chan JA, Blaszkowsky LS, Enzinger PC, et al. A multicenter phase II trial of single-agent cetuximab in advanced esophageal and gastric adenocarcinoma. Ann Oncol. 2011;22(6):1367-1373.

105. Gold PJ, Goldman B, Iqbal S, et al. Cetuximab as second-line therapy in patients with metastatic esophageal adenocarcinoma: a phase II Southwest Oncology Group Study (S0415). J Thorac Oncol. 2010; 5(9):1472-1476.

106. Schoennemann KR, Bjerregaard JK, Hansen TP, et al. Biweekly cetuximab and irinotecan as second-line therapy in patients with gastroesophageal cancer previously treated with platinum. Gastric Cancer. 2011;14(3):219-225.

107. Ilson DH, Kelsen D, Shah M, et al. A phase 2 trial of erlotinib in patients with previously treated squamous cell and adenocarcinoma of the esophagus. Cancer. 2011;117(7):1409-1414.

108. Dragovich T, McCoy S, Fenoglio-Preiser CM, et al. Phase II trial of erlotinib in gastroesophageal junction and gastric adenocarcinomas: SWOG 0127. J Clin Oncol. 2006;24(30):4922-4927.

109. Janmaat ML, Gallegos-Ruiz MI, Rodriguez JA, et al. Predictive factors for outcome in a phase II study of gefitinib in second-line treatment of advanced esophageal cancer patients. J Clin Oncol. 2006;24(10): $1612-1619$.

110. Ferry DR, Anderson M, Beddard K, et al. A phase II study of gefitinib monotherapy in advanced esophageal adenocarcinoma: evidence of gene expression, cellular, and clinical response. Clin Cancer Res. 2007;13(19):5869-5875.

111. Fuchs CS, Tomasek J, Cho JY, et al. REGARD: A phase Ill, randomized, double-blind ed trial of ramucirumab and best supportive care (BSC) versus placebo and BSC in the treatment of metastatic gastric or gastroesophageal junction (GEJ) adenocarcinoma following disease progression on first-line platinum- and/or fluoropyrimidine-containing combination therapy. J Clin Oncol. 2012;30.

112. Law S, Wong J. Current management of esophageal cancer J Gastrointest Surg. 2005;9(2):291-310. 


\section{Publish your work in this journal}

Cancer Management and Research is an international, peer-reviewed open access journal focusing on cancer research and the optimal use of preventative and integrated treatment interventions to achieve improved outcomes, enhanced survival and quality of life for the cancer patient. The journal welcomes original research, clinical \& epidemiological

studies, reviews \& evaluations, guidelines, expert opinion \& commentary, case reports \& extended reports. The manuscript management system is completely online and includes a very quick and fair peerreview system, which is all easy to use. Visit http://www.dovepress.com/ testimonials.php to read real quotes from published authors.

Submit your manuscript here: http://www.dovepress.com/cancer-management-and-research-journal 